\title{
A koronavírus-járvány okozta válság vállalati kockázati térképe az első hullám hazai tapasztalatai alapján
}

A Covid-19-járvány okozta gazdasági válság a vállalatok többségét készületlenül érte 2020 elején, pedig sokak szerint a helyzet korántsem volt váratlan, sőt hasonló járványokra a jövőben is számítanunk kell. Éppen ezért különösen fontos a pandémia okozta kockázatok áttekintése, rendszerezése, hiszen ez lehet egy későbbi sikeres kockázatkezelés kiindulópontja. Kutatásunkban forráselemzéssel, kérdőívezéssel és mélyinterjúk segítségével azonosítottuk a vírushelyzet okozta vállalati kockázatokat, valamint elkészítettük a járvány kockázati térképét is. Eredményeink azt mutatják, hogy a pandémia hatásai az arra adott társadalmi reakciók függvényében világszerte eltérők voltak ugyan, de összességében csak a korábban már ismert és jórészt kezelt kockázatok előfordulási gyakorisága nőtt, illetve e kockázatok együttmozgása erősödött általuk. Ennek mértéke az egyes ágazatokban eltérő volt, ám korábban nem látott, új típusú kockázatokat nem lehetett azonosítani. Fontos rámutatni arra is, hogy e kockázatok - részben a társadalmi reakciók módosulásával, részben pedig a vállalati tapasztalatok gyarapodásával - idővel módosultak, és voltak köztük a vállalkozások számára pozitív hatások is.

Journal of Economic Literature (JEL) kód: D81, G32, I15.

2020 elején a koronavírus-világjárvány annak ellenére váratlanul érte a vállalatokat a világon mindenütt, hogy az utóbbi évtizedekben gyakoribbá vált járványok miatt több szakértő is előrevetítette a pandémiák kialakulásának lehetőségét. A válság hatására a legtöbb vállalkozásnál csökkent a jövedelmezőség és a hatékonyság, miközben néhány ágazat és vállalat profitálni tudott a helyzetből.

A járványügyi szakértők egyetértenek abban, hogy a Covid-19 leküzdése után sem dőlhetünk hátra: újabb és újabb járványok terjedhetnek el világszerte - többek között a gazdasági kapcsolatok globalizálódása és a turizmus fellendülése nyomán. Éppen ezért a jelenlegi válsággal kapcsolatos kockázatoknak és azok hatásainak az áttekintése segítheti a vállalati és a politikai döntéshozókat abban, hogy jobban felkészüljenek a jövőben várható járványokra. Elemzésünk célja ezért a Covid-19-járvány első

Juhász Péter habilitált docens, Budapesti Corvinus Egyetem (e-mail: peter.juhasz@uni-corvinus.hu). Szabó Ágnes egyetemi adjunktus, Budapesti Corvinus Egyetem (e-mail: agnes.szabo2@uni-corvinus.hu). A kézirat első változata 2021. február 28-án érkezett szerkesztőségünkbe.

DOI: https://doi.org/10.18414/KSZ.2021.k.126 
hulláma okozta válsághoz kapcsolódó kockázatok megjelenési formáinak és következményeinek feltérképezése, valamint egy kockázati térkép összeállítása, amely a hasonló helyzetek kezelésében segíthet a jövőben.

Cikkünkben az ERM (Enterprise Risk Management, azaz integrált vállalati kockázatkezelési) rendszerek gyors áttekintését és a kutatási módszertan ismertetését követően először az azonosított kockázatok eredetét, majd pedig a kockázatok közvetlen és közvetett megjelenési formáit mutatjuk be. Nemzetközi és hazai szakirodalmi források alapján nem csupán magukat az okozott problémákat ismertetjük, hanem - kvalitatív kutatásainkra, tartalomelemzésünkre, az elkészített mélyinterjúinkra, valamint a kérdőíves kutatásunk nyitott kérdéseire adott válaszokra alapozva - a hazai gyakorlatot is bemutatjuk. A cikk legfontosabb eredménye a járvány első hullámának tapasztalataira épülő, az azonosított üzleti következményeket összefoglaló kockázati térkép.

\section{Vállalati kockázatkezelési rendszerek}

Ismeretes, hogy az integrált vállalati kockázatkezelési rendszer (Enterprise Risk Management -ERM) müködtetése hozzájárulhat a magasabb tulajdonosi érték megteremtéséhez (Nocco-Stulz [2006]). Az újabb eredmények (Anton [2018], Silva és szerzőtársai [2019]) ugyanakkor arra is rámutatnak, hogy az ERM alkalmazása versenyelőnyből fokozatosan belépési korláttá válik, különösen a nagyobb, tőzsdén jegyzett cégek esetében. Ez pedig nemcsak a fejlett gazdaságokra igaz, hanem még az olyan, nem az élbolyba tartozó országokra is, mint Románia vagy Brazília.

Minden kockázatkezelési folyamatnál elengedhetetlen, hogy a kockázatokat minél teljesebb körben tárjuk fel (Nocco-Stulz [2006]) és egymást nem fedő, diszjunkt halmazokba gyüjtsük. Ez azért fontos, hogy az egyes halmazok kockázatgazdáinak felelössége világosan elkülöníthető legyen, és egyetlen kockázati terület se maradjon a felelősség szempontjából lefedetlen. E halmazokat többféle szempont szerint alakíthatjuk ki: a kockázatokat elkülöníthetjük eredetük szerint (miért történik? mi okozza?), megjelenési formájuk és hatásuk alapján (hogyan szembesülünk vele a szervezetnél?), valamint a következményeik szerint (mit okoz?) is. Így például a 2020 tavaszán Magyarországon bevezetett járványügyi intézkedések (eredet) a távmunka szélesebb körü alkalmazásához (hatás) vezettek, ami IT-eszközök beszerzését igényelte, megnövelte az informatikai képzések iránti igényt, valamint fokozta az adatvesztés és a külső informatikai támadások esélyét (következmények) is.

Ha felismerjük, hogy pontosan milyen folyamatokkal állunk szemben, az segíthet meghatározni, hogy milyen kockázatkezelési eszközre van szükség és lehetöség, és hogy miként lehet ezt az eszközt alkalmazni. Az eredet szerinti osztályozás például megmutathatja, hogy mire kell figyelnünk az előrejelző rendszerek kiépítésekor; a hatások inkább a felkészülést és a kockázatkezelési intézkedések kiépítését segítik; míg a következmények összegzése módot ad a kockázat hatásainak számszerüsítésére és a kockázatkezelés hatékonyságának mérésére, fejlesztésére is (Murphyés szerzötársai [2020]). 
A három dimenzió szétválasztása döntő fontosságú a felelősségi körök meghatározásakor, valamint azok üzleti területek és szakemberek közötti felosztásakor is. Az a felelösségi rendszer, amelyben a következmények (például likviditási kockázatok) keverednek a megjelenési formákkal (behajtási kockázatok) vagy az eredet (piaci kockázatok) típusaival, komoly konfliktusokat okozhat a felelösök között, nehezítheti a megfelelö reakciókat, növelheti a védekezési költségeket - és ezáltal az optimálistól jelentősen elmaradó kockázatkezeléshez vezethet.

A szervezeti és pénzügyi rugalmasság fenntartása érdekében a vállalati kockázatkezelési rendszerek a kevéssé valószínü, úgynevezett feketehattyú-eseményekre általában idö- és költségtartalékokat építenek be a tervekbe. Ez a megoldás jól müködhet a rövid távú, rövid ideig ható, akár korábban még soha nem tapasztalt kockázatok esetében is. A koronavírus-járvány okozta válság azonban nemcsak hosszú távon velünk marad, de egyes iparágakban a következményei is radikálisak lehetnek. $\mathrm{Az}$ ilyen ritka, de nagy hatású kockázati eseményekkel a komoly felkészültséget igénylö válságkezelési tervek foglalkoznak, amelyektől idegen az egyszerű idő- és költségtartalékok alkalmazása. Éppen ezért a járvány okozta kockázatok alapján összeállított, jól strukturált kockázati térkép segíthet abban, hogy lássuk, miként módosíthatók a meglévő kockázatkezelési politikák - nem csupán a jelenlegi, de a jövőben várható, újabb pandémiák következményeinek hatékonyabb kezelése érdekében.

Többek, így például Murphy és szerzőtársai [2020] szerint a koronavírus-járvány egyáltalán nem feketehattyú-esemény. Hozzá hasonló esemény több is történt már az elmúlt években - például a SARS (2002-2003), a H5N1 vírus vagy más néven madárinfluenza (2003-2007), a sertésinfluenza néven ismert H1N1 vírus (2009), a MERS (2012+), valamint az ebola (2013-2016) -, és számos szakértő hívta fel a figyelmet világméretű járványok lehetséges bekövetkeztére. Ennek alapján pedig ennek a járványnak nem kellett volna váratlanul érnie a világot, így a jelenlegi válság ilyen értelemben a megelőző időszak kockázatelemzéseinek és előrejelzéseinek hiányosságaira is rávilágít. Ráadásul a kutatásunk eredményei szerint a válság nem járt új, korábban ismeretlen kockázati formák megjelenésével - ez pedig szintén ellentmond a feketehattyú-események definíciójának.

\section{Kutatási módszertan}

Tekintettel arra, hogy a koronavírus-járvány gazdasági hatásai Ázsiában 2020 legelején, Európában pedig 2020 márciusában jelentkeztek, a cikk készítésekor, 2020 nyarán hagyományos mérési eredmények csak nagyon korlátozottan álltak a rendelkezésünkre. A statisztikák nemritkán csak 6-12 hónappal az adott időszak lezárását követően érhetök el, és a tőzsdén jegyzett cégek gyorsjelentései is rendszerint csak 45 nappal az adott időszak vége után elemezhetők. Ráadásul ezek a források szinte kizárólag a válság számszerüsített következményeinek nyomon követésére adnak lehetőséget, és azokat is csak összevontan lehet belölük elemezni. Így az okok és a hatások rejtve maradnak.

Mindezt mérlegelve a tanulmányunk többféle forrásra és módszertanra épít, jellemzően kvalitatív (feltáró) kutatással. A legfrissebb nemzetközi szakirodalom és az 
elérhető statisztikák áttekintésén túl a való életből vett, hazai vállalati tapasztalatokat gyüjtöttünk a Covid-19 első hulláma keltette kockázatok különböző megjelenési formáiról. A magyar helyzet áttekintésére a következő forrásokból dolgoztunk:

1. Kvalitatív mélyinterjút készítettünk az Aon vállalati egészségfejlesztő programjának egyéves nyomon követése részeként, amelynek során a Covid-19 hatásait is feltérképeztük a munkavállalók körében. A Longevity Projektben részt vevő tíz tanácsadó közül végül hatan vállalták az interjút, hárman közülük több mint tíz éve a vállalatnál dolgoztak. Ketten voltak 35 év alattiak, és valamennyiüknek volt lehetősége otthonról dolgozni a pandémia okozta lezárások idején. A járványhelyzetre tekintettel a mélyinterjúk nem személyesen, hanem online módon történtek 2020 márciusában, és jellemzően 60 percig tartottak.

Emellett mélyinterjúkat készítettünk 2020 júliusában három, a vállalati egészségfejlesztés területén dolgozó szakemberrel (Márky Ádámmal, a Longevity Project alapító orvos igazgatójával, Faragó Istvánnal, a Stressz-M és a Mental Coffee alapító tulajdonosával, valamint Horváth Emillel, az Egészségesebb Munkahelyekért Egyesület elnökével), nagy hangsúlyt helyezve a Covid-19 munkavállalókra gyakorolt hatásaira (Márky [2020], Faragó [2020], Horváth [2020]). Az összesen kilenc mélyinterjú célja a munkavállalói oldalon megjelenő kockázatok minél alaposabb feltérképezése, e kockázatok emberi oldalának jobb megértése volt.

2. Elvégeztük a KÜRT Akadémia Live 2020 áprilisa és júniusa között szervezett, nyolc online szakértöi panelbeszélgetésének a részletes tartalomelemzését is (KAL [2020a-h] - lásd a Függelék F1. táblázatában). Az online kerekasztal-beszélgetések meghívott előadói különböző szektorokból (bank, élelmiszeripar, járműipar, távközlés, energia, szolgáltatások, oktatás) érkeztek, és a válság különböző területeiröl és kockázatairól osztották meg tapasztalataikat.

3. A munkavállalók által érzékelhető kockázatok feltérképezésére 2020 júliusában egy online kérdöíves kutatást indítottunk. E cikk elkészítéséhez a beérkezett 86 választ is felhasználtuk, ami nem reprezentatív minta ugyan, de informatív jellegü eredményeket adott. A munkánk során a „Milyen kockázatok és nehézségek vannak home office-ban a koronavírus-járvány alatt?” és a „Tapasztalatai szerint milyen elönyei vannak a helyzetnek?" nyitott kérdésekre adott válaszokat értékeltük, illetve dolgoztuk fel.

Az alábbiakban a nemzetközi, valamint az empirikus forrásokból összegyüjtött információkat tekintjük át. Cikkünk döntően az első hullám tapasztalataira, forrásaira épül, de ahol a cikk készítésekor már volt elérhető információ, ott természetesen a második hullám hatásaira is kitérünk.

\section{A kockázat eredete és megjelenési formái}

2019 decemberében egy új típusú koronavírust fedeztek fel Kínában, amely a SARSCoV-2 vagy röviden a Covid-19 nevet kapta. Az Egyesült Államok Országos Allergia- és Fertöző Betegségek Intézetének (National Institute of Allergy and Infectious Diseases) igazgatója, Anthony Fauci a vírus halálozási rátáját körülbelül 2 százalékra, 
míg a WHO 3,4 százalékra tette (CNN Health [2020]). A legtöbb ország - így hazánk is - 2020 márciusában járványügyi intézkedéseket hozott, és részleges zárlatot vezetett be a vírus terjedésének megakadályozására. Az iskolákat és a közintézményeket bezárták, a tömegközlekedés és általában a személyek mozgása korlátozott volt, a kórházak a működésüket a nem halasztható esetekre és a koronavírussal fertözöttek kezelésére korlátozták. Az embereknek maszkot kellett viselniük és távolságot kellett tartaniuk a nyilvános helyeken. Néhány ország (például Hollandia vagy Svédország) a gazdasági károk minimalizálására ennél lazább szabályozást követett.

A vállalati szinten megjelenő kockázatok oka elsődlegesen nem maga a koronavírus-járvány volt, hanem az arra adott társadalmi (felvásárlási hullám, internetes rendelések) és politikai döntéshozói reakciók (üzletbezárás, kijárási tilalom), illetve a betegség munkaerőpiaci hatásai. A járványügyi mutatók és a kormányzati intézkedések országonként eltérők voltak, ezért a vállalatok országonként némileg eltérő kockázati okokkal szembesültek.

Az 1. táblázat a Magyarországon előforduló leggyakoribb problémákat mutatja be a Magyar Kereskedelmi Kamara által müködtetett Gazdaság- és Vállalkozáskutatási Intézet által 2020 márciusában készített felmérés alapján (Statista [2020a]). A felmérés idején a cégek mindössze 2 százaléka válaszolta azt, hogy nem tapasztalt semmilyen káros hatást, a leggyakoribb problémának pedig a kereslet csökkenését tartották.

\section{1. táblázat}

A Covid-19-ből eredő kockázatok leggyakoribb megjelenési formái Magyarországon

Probléma

Előfordulási gyakoriság (százalék)

A KERESLETI OLDAL VÁLTOZÁSAI

A kereslet csökkenése (kevesebb ügyfél, kevesebb megrendelés) 72

A nyilvános rendezvények tilalma és a rövidített nyitvatartás

Kevesebbet rendelnek, akiknek beszállítunk

19

A külföldi gyárak és ügyfelek kevesebbet rendelnek

A külföldi anyavállalat csökkentette megrendeléseit

2

Az ELLÁTÁSI LÁNC ÉS A TERMELÉS ZAVARAI

Be kellett zárnunk

Importhelyettesítés szükséges

10

Munkaerőhiány 6

Profitabilitási gONDOK

Az ágazat árai csökkentek, így visszaesett a jövedelmezőség 6

Forrás: Statista[2020a] alapján.

Az alábbiakban a nemzetközi irodalom és a saját empirikus kutatásaink - leginkább a tartalomelemzésünk - eredményei, illetve kategóriái alapján tekintjük át a kockázatok megjelenési formáit. 


\section{A kereslet változásai}

A kereslet időbeli eloszlásának bizonytalansága általános kihívást jelent a gazdaságban. A kereslet kiszámíthatatlan, hirtelen változásai azonban még nehezebben kezelhetők. Időre van szükség a további termelési kapacitások felállításához, ugyanakkor a termelés csökkentésével is további költségek merülhetnek fel, miközben romlik a vállalkozás likviditása és jövedelmezösége is. A válság során többféle keresleti hatást lehetett tapasztalni.

A háztartások felhalmozni, raktározni akartak egyes termékeket 2020 tavaszán, a járvány első hullámának megjelenésekor. Ez bizonyos árucikkekből rövid idő alatt két-három hónapig tartó hiányhoz vezetett a kiskereskedelemben. A kereslet radikális növekedésével nemcsak e termékek gyártói, hanem az importáló vállalatok is szembesültek. Emellett az egészségügyi, valamint a házhoz szállítás és az egyéb online szolgáltatások iránt növekedett meg számottevően a kereslet. „Az online értékesítés most új dimenziókat ér el." (KAL [2020e])

A barkácsüzletek nagyon jól teljesítettek ebben az időszakban. A lezárások idején sokan otthonfelújításba kezdtek, vagy önállóan végeztek el kisebb-nagyobb otthoni javítási munkákat. Ez a tendencia a szektor kiskereskedelmi forgalmának fellendüléséhez vezetett: 2020 első felében az árbevétel 9,2 százalékkal nőtt Magyarországon az elöző évihez képest (Torontáli [2020]). Ugyanez a növekedés 15,6 százalékos volt Németországban (Welt.de [2020a]). A festékek és a hozzájuk kapcsolódó kiegészítő termékek forgalma 37,6 százalékkal bővült, és a kertészeti eszközök és bútorok kiskereskedelmi árbevétele is több mint 20 százalékkal nőtt. Rövid távon a kiskereskedelem egésze, az online piacterek, a logisztika és a gyógyszeripar forgalma is növekedni tudott. Középtávon az informatika és az automatizálás lehet a pandémia okozta helyzet nyertese, azon ágazatokkal együtt, amelyek sikeresen tudják minimalizálni az elbocsátások okozta veszteségeket (Szolidaritási Akciócsoport [2020a]).

A válság miatt ugyanakkor több terület is hatalmas veszteségeket szenvedett el. Xiong és szerzőtársai [2020] a közlekedési, az élelmiszer- és ital-kiskereskedelmi, a szállodai és turisztikai, a postai, a raktár-, az ingatlanpiaci, a szórakoztató- és az építőipari szolgáltatásokat találták a legkiszolgáltatottabbnak. Poór és szerzőtársai [2020] szerint is a kereslet csökkenése volt a pandémia leginkább negatív hatása a vállalkozásokra. $\mathrm{Az}$ éttermek, bárok, szállodák és mozik zárva tartottak, az utazási irodák és a rendezvényszervezök gyakorlatilag nem müködhettek. A fodrászok és a kozmetikusok ekkor még nyitva maradhattak ugyan, de a forgalmuk radikálisan visszaesett.

Mivel eközben sokakat fizetés nélküli (kényszer)szabadságra küldtek, a fogyasztói jövedelmek csökkentek, ez pedig valamennyi iparág keresletét érinthette. Poór és szerzőtársai [2020] több mint 500 szervezetet érintő felmérése szerint az első hullámban a fizikai betanított és az adminisztrátori munkaköröket érintette a létszámcsökkentés Magyarországon. A szálloda- és vendéglátóiparban elsősorban a felszolgálói és szakácsmunkakörökben; az iparban az operátori, míg a bolti kereskedelemben az eladói munkakörökben dolgozókat küldték el a kereslet visszaesése miatt. Jellemzően eladói, értékesítői, felszolgáló-, szakács-, pultos- és cukrászmunkakörök, valamint operátori és asszisztensi pozíciók szüntek meg az első hullámban. 
Ezzel szemben az áru-összekészítő, informatikus-, futár-, mérnök- és ügyfélszolgálati munkatárs munkakörökben bővült a foglalkoztatotti létszám az e területeken tapasztalt keresletélénkülés miatt.

A válság világszerte a kevésbé képzett munkavállalókat sújtotta leginkább. A McKinsey [2021a] felmérése rámutatott, hogy az Egyesült Államokban a spanyol ajkú vagy afroamerikai, az alacsony képzettségü, a kisebb keresetü és a női munkavállalók sokkal nagyobb arányban veszítették el munkájukat, és várhatóan nehezebben is találnak majd ismét állást.

Ezt támasztja alá az NBC News (Wronski [2020]) közvélemény-kutatása is, amely szerint a megkérdezettek 41 százaléka nagyon aggódott amiatt, hogy a Covid-19 negatív gazdasági hatással lesz a háztartása pénzügyeire. A Robert Wood Johnson Alapítvány jelentése (Gonzalez és szerzőtársai [2020]) szerint pedig a 19 év alatti gyermekekkel élő szülők 43 százaléka szembesült gazdasági kihívásokkal a járvány miatt. A hazai tapasztalatok ezzel összecsengenek. „A háztartásunk jövedelme csökkent, ezért körültekintőbbnek kell lennünk a kiadásokkal is." (Válasz a kérdőívünkre 2020 augusztusában.) Ezzel együtt a háztartások hitelfelvételi hajlandósága is jelentősen csökkent. „A háztartások új jelzáloghitel-állománya a felére esett vissza." (KAL [2020e])

Az empirikus forrásainkból levonható tanulságok alapján három mintázatot azonosithatunk a Covid-19 első hullámának ágazati hatásaiban:

1. Megugró kereslet, ellátási gondok. Miközben egyes ágazatokban (például az orvosi segédeszközök gyártásában) a termelést drámaian növelni kellett volna, a hagyományos importcsatornák sokszor még a korábbi ellátási szintet sem tudták biztosítani. Az érintett vállalatok az első hullám után normalizálódó anyagellátásról, később pedig többnyire a vártnál nagyobb értékesítésről és jobb jövedelmezőségről számoltak be.

2. Erőteljes keresletingadozás. A háztartások a járvány első hullámának elején bizonyos termékekből komoly készleteket halmoztak fel, majd fokozatosan felélték őket. Így a hirtelen megugró kereslet általános visszaesésbe fordult, mielött normalizálódott volna. A túlórákért kifizetett összegek, az eseti fuvarozási többletigény, valamint a további raktárhelyiségek magasabb költségei összességében általában rontották az érintett cégek jövedelmezőségét.

3. Egyes ágazatokban a válság idején jelentösen lecsökkent kereslet később sem normalizálódott. Az utazási és szállodai szolgáltatások, valamint a vendéglátás egy része teljesen megszűnt, a kényszerből bevezetett házhoz szállítás sokszor a túléléshez is kevés volt. Ezekben az ágazatokban sok vállalat nagyon nehezen vagy egyáltalán nem élte túl az első két hullámot.

\section{Az ellátási láncok zavarai}

A Fortune-1000 cégeinek 94 százaléka jelentett a koronavírus miatt szakadásokat az ellátási láncokban mind a kínálati és keresleti, mind pedig a logisztikai oldalon (Ivanov [2020]). A nemzetközi ellátási láncokat blokkolták a zárt határok és a nemzetközi fuvarozás kényszerű korlátai. Ez a késztermékkészlet növekedését okozta, miközben az alapanyagkészletek kimerültek. A cégek kénytelenek voltak helyi beszállítókat keresni, 
ez pedig gyakran lehetetlen volt. „A magyar gazdaságban elsősorban a kiesö olasz és kínai import vezetett komolyabb ellátási problémákhoz." (KAL [2020c])

Ivanov [2020] egy szimuláción alapuló kutatással arra a következtetésre jutott, hogy nemcsak a három területen bekövetkezett zavar mértékétől és hosszától függ a járvány hatása az ellátási láncokra, hanem attól is, hogy ezek a tényezők időben hogyan viszonyulnak egymáshoz. Amikor a keresleti, a logisztikai és a kínálati sokk szinte egyszerre történik, a kilábalás időben átfedi egymást. Ha a sokkok fellépte időben eltérő, vagy kevés az átfedés, a következmények általában radikálisabbak. A sokkok iránya szintén létfontosságú. Ha a kínálat csökken, miközben a kereslet fokozódik (ahogyan azt több ágazat esetében láthattuk), a következmények még súlyosabbak lehetnek, különösen, ha a potenciálisan elvesztett nyereséget is figyelembe vesszük.

A járvány nagyobb veszélyt jelent a kevésbé összekapcsolt területeket lefedö ellátási láncokra, mint a helyiekre. Erre különösen azért fontos odafigyelni, mivel a területi diverzifikációval a helyi katasztrófák hatásainak korlátozása érdekében a vállalatok gyakran távoli helyeket választanának tartalékok gyártásához vagy a beszerzéshez.

\section{Az alkalmazottakra gyakorolt hatások}

A pandémia számos hatása közvetlenül a munkavállalókat érinti, és rajtuk keresztül befolyásolja a cégek üzleti teljesítményét is. E kockázatokat sem szabad elhanyagolni, mivel ezek megfelelö kezelése mérhetően hozzájárulhat a munkáltató üzleti sikeréhez. Ramos és szerzőtársai [2020] kimutatták, hogy a munkahelyi egészségvédelmi és biztonsági kérdések integrálása a szervezet kockázatkezelési rendszerébe nemcsak a munkavállalók, hanem az egész szervezet számára is hozzáadott értéket teremthet. Korábban Aldana [2001], valamint van Dongen és szerzötársai [2011] is kiemelték, hogy a munkavállalók jólléti programjai részvényesi értéket generálnak.

\section{Munkavégzés otthonról}

Az otthonról történő munkavégzést sok alkalmazott számára kötelezővé tették, ám a home office nem volt mindenkinek optimális megoldás. Bár az otthon maradás olcsóbbnak tünik, az így végzett munka megterhelöbb lehet, különösen, ha közben gyerekekről vagy más családtagokról kell gondoskodni. „A vasalódeszkám íróasztalként is szolgált.” (KAL [2020f]) „A háztartási feladatok, a gyermekek segitése a tanulásban és a közös otthoni munkavégzés a szülök többségének túl sok volt. Ezek a követelmények mentálisan és fizikailag is túlterhelték az alkalmazottakat." (KAL [2020f])

Schwantes [2019] felmérése szerint az irodai alkalmazottakhoz képest a távmunkások évente 4523 dollár üzemanyagköltséget takarítanak meg, és az egészségesebb életmódra is jobban tudnak figyelni, mivel hetente átlagosan 25 perccel több idejük jut fizikai aktivitásra az irodában dolgozókhoz képest. Ugyanakkor a távmunkások 29 százalékának jelent problémát a munka és a magánélet egyensúlyának megteremtése. 
2. táblázat

Az otthoni munkavégzés legfontosabb kihívásai

NEMZETKÖZI KUTATÁSOK

Xerox [2020]

- Egyesült Államok, Kanada,

Informatikai kérdések, csapattagok közötti kommunikáció,

Egyesült Királyság, Németország,

Franciaország

Statista [2020b]

- Dánia

összpontosítás fenntartása

Statista [2020c]

- Egyesült Királyság

Statista [2020d]

- világszinten

Személyes kapcsolatok hiánya, gyerekek gondozása, a közvetlen irányítás hiánya

Meghosszabbodott munkaidő, a munka és a magánélet konfliktusai

Együttműködési nehézségek, elmagányosodás, folyamatos online jelenlét

MAgYAR KUTATÁSOK

HRFEST [2020]

Összpontosítás, a munka és a magánélet szétválasztása, a testi és lelki egészség megőrzése

Kazainé [2020]

A kapcsolattartás hiánya, a visszajelzések hiánya, a munkaidő és az otthoni feladatok elkülönítése

Bakonyi-Kiss-Dobronyi [2020] Stressz, a hatékonyság csökkenése, párhuzamosan dolgozni és a családdal, háztartással, gyermekekkel foglalkozni

Haromkiralyfi.hu [2020]

Magány, informatikai problémák,

túl sok online kommunikáció, monotonitás

Forrás: saját szerkesztés.

A témában megjelent irodalom is alátámasztja ezeket a megállapításokat. Az otthonról végzett munka legfontosabb kihívásai világszerte nagyon hasonlók (lásd a 2. táblázatot). Arkcoll [2020a, 2020b] áttekintést ad arról, hogy az otthoni munka miként változott a koronavírus hatására. Eredményei rámutatnak arra, hogy az online együttmüködésnek van egy tanulási görbéje: egy hónap elteltével a negatív hatások jelentősen csökkentek, miközben az értekezletek száma - igaz, egy magasabb szinten, de - stagnált. A magyar munkavállalók is érzékelték ezen problémákat. „Többet ültünk meetingeken..., és ezek hosszabbak és gyakoribbak voltak." (Válasz egy Longevity-interjúból.)

Arkcoll [2020a, 2020b] azt is leírta, hogy a válság elötti szinthez képest az értekezleteken általában kevesebben vannak, a vezetők többet kommunikálnak, és gyakoribbá váltak a vezetőkkel az egyszemélyes megbeszélések. A Xerox [2020] arról számolt be, hogy az általa megkérdezett cégek 82 százaléka tervezi a visszatérést az irodai modellre. Ugyanakkor a cégek 58 százaléka azt is jelezte e felmérésben, hogy felülvizsgálja korábbi home office politikáját.

Egy lehetséges megoldás, ha a cégek felajánlják az alkalmazottaknak, hogy eldönthessék: otthonról vagy az irodában szeretnének-e dolgozni a jövőben. Ez az új trend forradalmasíthatja az irodapiacot, ugyanis igény lehet kicsi (akár egyfős), de teljesen felszerelt irodahelyiségek bérlésére nagyon rövid (akár egynapos) időszakokra, 
egyfajta „irodai Airbnb”-ként (Welt.de [2020b]). Fennáll a veszélye annak, hogy a vállalatok egy része ezt a tendenciát a költségek csökkentésére használja, és nem a munkavállalóé lesz a választás lehetősége. Kraus és szerzőtársai [2020] kutatási eredményei azt mutatják, hogy az állandóan változó irodai környezet további terhet jelenthet az alkalmazottak számára, ez pedig fokozott stresszhez vezethet.

Online kérdőívünk eredményei alapján az öt legjelentősebb nehézség az otthoni munkavégzés során Magyarországon a következő volt: 1. a személyes kapcsolatok hiánya, 2. a technikai (informatikai) nehézségek, 3. a fókuszálási problémák, 4. a munka és a magánélet határainak tartása, valamint 5 . az otthonról végzett munka közben a háztartás vezetése és a gyermekek segítése a tanulásban.

\section{Fokozott terhelés}

A felmérések szerint minden ötödik alkalmazott úgy érezte, hogy a koronavírus-járvány valamilyen szinten zavart okoz a munkájában, és nagyjából kétszer annyian emelték ki a családi felelösségvállalás miatti nehézségeket (Wellable [2020a]). Egy 2020. márciusi dán felmérésben minden tizedik válaszadó a gyermekek gondozását jelölte meg a home office időszakának fö kihívásaként (Statista [2020b]). Romániában az emberek egyharmada nehezen tudta fenntartani az egyensúlyt a gyermekek gondozása és az otthonról végzett munka között (Statista [2020e]). Az Egyesült Királyságban megkérdezett munkavállalók egynegyede azt állította, hogy a munka behatol a személyes életébe is (Statista [2020c]).

Elsősorban azok érezték komoly kihívásnak a home office-t, akik számára az otthoni munkavégzés újdonság volt. Bakonyi-Kiss-Dobronyi [2020] szerint az „új távmunkásoknak" kétszer olyan gyakran okozott problémát a munka és a család egyensúlyának fenntartása, mint az e téren tapasztalt kollégáiknak. Különösen a legalább négy főt számláló háztartások panaszkodtak megnövekedett stresszröl és csökkenő hatékonyságról. A mi megkérdezettjeink és a KAL résztvevői is elsősorban a szintén otthonról tanuló gyermekkel és a háztartás vezetésével kapcsolatos pluszterheket nehezményezték. „Két meeting között megcsinálja a gyerek házi feladatait, föz, takarít, folyton mosolyog, és közben megnézi az e-mailjeit - ez nem normális." (KAL [2020f]) "Lehetetlen két kisgyerekkel egy lakásban dolgozni." (KAL [2020f]) „Túl sok ember volt otthon. Fözni kellett a gyerekeknek, szórakoztatni öket, és segiteni öket a tanulásban. Azotthoni munka nagyszerü lenne, ha egyedül lennék ot thon.” "Egyszerre vagyok anya, alkalmazott és házvezetőnö. Így rendszeresen dolgoznom kell az éjszaka folyamán." (Válaszok az online kérdőívünkre.)

\section{Lezárások, kijárási tilalom, karantén}

A legtöbb országban szigorúan korlátozták, hogy az emberek mikor és miért hagyhatják el otthonaikat. Magyarországon az első hullám idején például az időseknek külön bevásárlási sávjuk is volt. Az emberek csak a bevásárlás idejére vagy a munkahelyükre 
menet hagyhatták el az otthonaikat, így az idejük nagy részét a lakásukban kellett tölteniük. Ez pedig a legtöbb esetben növelte valamennyi családtag stressz-szintjét. A vonatkozó irodalmat áttekintve megállapíthatjuk, hogy az otthonmaradás következményei általában negatívak voltak. Sharma és szerzőtársai [2020] kimutatták, hogy a járvánnyal és a járványügyi intézkedésekkel kapcsolatos szorongás és depreszszió implicit napi költsége megközelítőleg 10 dollár. Emerson és szerzőtársai [2020] tanulmányozták a magány és a társadalmi elszigeteltség hatását a jóllétre, és szignifikáns negatív kapcsolatot találtak.

Nem feltétlenül romlott azonban minden munkavállaló életminősége. Wang és szerzőtársai [2020] arra jutottak, hogy Kínában a lezárások idején a dolgozók csökkentették ugyan a napi fizikai aktivitásuk mennyiségét, a válaszadók 23 százaléka azonban egészségesebb étrendre váltott; 30 százalékuk több zöldséget és gyümölcsöt fogyasztott; 75,2 százalékuk pedig nagyon jónak ítélte az alvásminőségét. A válság előtti és utáni paneladatok szerint (Recchi és szerzőtársai [2020]) a francia megkérdezettek jólléte javult a lezárások során.

Saját kutatásunk szerint itthon ez az időszak a legtöbb ember számára a bizonytalanságok, a félelmek és az extra stressz időszaka volt. A megkérdezettek az idejük nagy részét az online térben töltötték. „A virtuális valóságban könnyebben eltévedhetünk. Nehezebb kapcsolatban maradni a valósággal." (KAL [2020b]) A fizikai bizonytalanság mellett meghatározó volt a pszichikai bizonytalanság is. „Nagy volt a stressz, a pszichológiai biztonság teljesen elveszett... Ez nem normális." (KAL [2020h]) Ennek a kockázatnak pedig egyéni, vállalati és társadalmi következményei egyaránt lehettek. „Az otthoni munka második hetére mindenki panaszkodott valamilyen gyomorfájásra." (KAL [2020a])

\section{Az egészségügyi szolgáltatások korlátozott elérhetősége}

A válság idején számos egészségügyi intézmény bezárt, vagy a nem halasztható esetekre és a koronavírussal fertőzöttek kezelésére korlátozta a működését, a nem sürgősségi ellátásokat pedig hónapokkal elhalasztotta. Néhány krónikus beteg meg sem próbált ellátáshoz jutni. Az orvosi létesítményekhez való korlátozott hozzáférés többféleképpen csökkentheti a jóllétet (Andrade [2020a]). A különféle betegségek késői diagnosztizálása és kezelése fokozott károkat okozhat mind mentálisan, mind pedig testileg. Az orvosi beavatkozásra való várakozás növeli a stresszt, veszteségekhez és a munkahelyek bizonytalanságához vezethet. A pszichoszomatikus változások ráadásul évekig rejtve maradhatnak, és az úgynevezett presenteeism (testileg vagy lelkileg betegen való munkavégzés, munkahelyi jelenlét) növekedéséhez vezethet (Assari-Lankarani [2016]). A kezelésekre váró betegek fizikai aktivitása csökkenhet, a mentális problémák elhízáshoz vezethetnek, amelynek a negatív következményei szintén évtizedekkel később jelentkezhetnek (Andrade [2020b]). 


\section{A személyes jóllét romlása}

A közvetlen egészségügyi hatások mellett a Covid-19 okozta válság számos módon befolyásolta az emberek jóllétét. A leginkább érintett iparágak alkalmazottai tömeges elbocsátásokkal szembesültek, vagy kénytelenek voltak fizetés nélküli szabadságra menni, illetve részmunkaidős állásra váltani. A pandémiához kapcsolódó stressz az emberek mentális egészségére is negatívan hatott. A Society for Human Resource Management jelentése szerint - amely több mint ezer amerikai alkalmazott 2020 áprilisában gyüjtött válaszain alapult - minden negyedik munkavállaló depressziósnak érezte magát; több mint 40 százalékuk kimerültséggel küzdött; több mint 20 százalékuknak volt gondja a koncentrációval; és több mint egyharmaduk szenvedett energiahiánytól (Wellable [2020a]). A 2020. júniusi felmérések azt mutatták, hogy az alkalmazottak körében fokozódott a depresszió (54 százalékkal), a poszttraumás stressz (49 százalékkal), és nőtt az általános szorongásos rendellenességek (41 százalékkal) és a függőségek (11 százalékkal) kockázata. Ezek a számok szignifikáns emelkedést mutatnak a járvány előtti adatokhoz képest (Wellable [2020b]).

A felmérések szerint a nőket még inkább érinti a stressz, mint a férfiakat. Egy amerikai kutatás szerint 2020 májusáig az amerikai dolgozó nők körében a depresszió gyakorisága 83 százalékkal nőtt február óta, miközben a dolgozó férfiak körében a növekedés ugyanezen időszakban 36 százalékos volt. A szorongás a dolgozó nők körében 52 százalékkal, a férfiak körében pedig 29 százalékkal nőtt 2020 februárja óta (Total Brain [2020]). Czeislerés szerzőtársai [2020] az Egyesült Államok adatait elemezve 2020 augusztusában arra is rámutattak, hogy a koronavírus következtében a 18 év felettiek 41 százaléka tapasztalt magán legalább egyféle negatív mentális hatást, 31 százalékuk depresszióra panaszkodott, 13 százalékuk pedig elismerte, hogy különféle szerek használatába kezdett, vagy növelte azok korábban fogyasztott mennyiségét. A megkérdezettek csaknem 11 százaléka számolt be öngyilkos gondolatokról a megelőző 30 napban. Ez a probléma az átlagosnál jóval erősebben érintette a 18-24 éves korosztályt (26 százalék), a faji és etnikai kisebbséghez tartozókat (19 százalék) és a más felnőtteket térítésmentesen gondozókat (31 százalék). Ezeket a negatív hatásokat nem lehet csak a kijárási korlátozások számlájára írni. A mentális problémák elöfordulási gyakorisága Japánban is többszörösére nőtt (Fukase és szerzőtársai [2021]), pedig ott nem voltak a lakosság mozgásának szabadságát érdemben korlátozó intézkedések.

A megkérdezett hazai egészségügyi szakembereink véleménye szerint (Márky [2020], Faragó [2020], Horváth [2020]) számos tényezö befolyásolhatja, hogy ki hogyan éli meg a karanténidőszakot. Az életkor, az egészségi és családi állapot, a támogató környezet (barátok és rokonok), a lakhely, valamint az életkörülmények egyaránt befolyásoló tényezők lehettek. Márky [2020] szerint a vezetők számára volt nehezebb ez az időszak, különösen, ha el is kellett bocsátaniuk munkatársakat. Horváth [2020] kiemelte, hogy az extrovertáltaknak általában nehezebb megbirkózniuk egy karanténhelyzettel.

A koronavírus-járvány jólléti hatása tehát egyéni tulajdonságoktól is függ. A tapasztalatok szerint sokkal hatékonyabban müködött a home office a családbarát vállalatoknál, valamint ott, ahol mind a vezetök, mind pedig az alkalmazottak 
felkészültebbek voltak a váratlan helyzetekre. A családbarát vállalkozásoknál a motiváció is jobban fenn tudott maradni (haromkiralyfi.hu [2020]). A Kürt Akadémia Live panelbeszélgetéseiben a két leggyakrabban említett kockázati tényező a személyes kapcsolatok hiánya és a mentális megterhelés volt. A személyes kapcsolatok hiányának két aspektusát külön is kiemelték a megkérdezettek:

1. Az ember alapvetően társas lény, így sokkal jobban érzi magát közösségben, mint egyedül, azaz szívesebben van a munkatársaival, mint egyedül, a szoba magányában. „Örömeink, müködésünk alapvetö forrása a személyes jelenlét... A social life hiányzik a legjobban.” (KAL [2020a]) „A szociális lét fontos állomása a munkahely... Egy kultúra, egy közeg vagyunk, együtt járunk inni, ebédelni, kávézni. Hol van ez most?" (KAL [2020a])

2. Ha egy alkalmazott nem találkozik a munkatársaival, számos lelki problémáját elfojtja, nem tudja „ventilálni”, ahogy ezt korábban akár észrevétlenül is tette. „Érzelmi nehézségeinkröl általában spontán találkozásokkor beszélünk, nem szervezünk erre külön meetinget most." (KAL [2020a])

Az egészségprogramoknak a lezárások idején is nagy szerepük volt. Aki korábban vagy éppen a karantén időszakában részt vett ilyeneken, sokkal kevesebb stresszről számolt be. Esetükben a hiányzó emberi kapcsolatokat is részben pótolták az állandó online találkozások „Megtudtuk, hogy a jóllétünk ebben a helyzetben is fontos. A menedzserek valóban törödnek velünk.” „Ujrakezdtük a receptek megosztását... Egy kolléga összegyüjtötte és megosztotta az online sportolási lehetöségeket... Éppen most kezdtem el használni a programon tanult tudatosságmeditációt. Nagyszerü, hogy van mihez nyúlni a pandémia idején." (Válaszok két Longevity interjúból.)

A home office lehetősége mellett az alkalmazottaknak nyújtott segítség legfontosabb formái a pontos információk, a hiteles kommunikáció, valamint a mentális egészségre való odafigyelés voltak. A pszichológus vagy coach segítségét, valamint az informatikai támogatást szintén nagyra értékelték a kutatásunk online kérdőívének kitöltői.

\section{Közvetett üzleti hatások}

A munkavállalókat közvetlenül sújtó kockázati hatások a munkáltatóknál többféle közvetett hatásként jelentkeztek. A következökben a leggyakrabban idézett hatásokat vesszük sorra.

\section{Információ- és innovációvesztés}

A kommunikációs forma, illetve csatorna változása gyakran információvesztéssel jár. A digitális kommunikáció nehézségei mellett a metakommunikáció terén is rendre gyengébben teljesítettek az alkalmazottak az új csatornákon. Az új kollégák integrációjánál az e-csatornák használata például kifejezetten hátrányos lehetett. A vállalati tapasztalatok alapján a kommunikáció online formája nemcsak nehezíti 
az információáramlást, de kevesebb teret enged a személyes érzések megosztására. Mindez hátráltathatja az innovációt is, hiszen az informális, személyes munkahelyi beszélgetésekből rendszerint új megoldások és ötletek is származhatnak. „Nincsenek informális pillanatok az online térben. Az offline beszélgetések növelték a hatékonyságot és az innovációt [a válság előtt]. Ez most nincs így.” (KAL [2020a])

\section{Menedzsmentproblémák}

Gajendran-Harrison [2007] már több mint egy évtizeddel a mostani válság előtt negatív kapcsolatot talált az otthonról végzett munka és a kollegiális kapcsolatok minősége között. A fizikai távolság korlátozza az együttműködési lehetőségeket, nemcsak az alkalmazottak, hanem a vezetők körében is. A szerzők arra a következtetésre jutottak, hogy az irodán kívüli munkavégzés rendszerint akadályozza a csapatmunkát és az interperszonális kapcsolatokat.

A projektek általában hosszabb ideig tartanak távmunkában, mint egyébként, miközben a képzés és a mentorálás is sokkal nehézkesebb (Cutter [2020]). Egyes munkáltatók szerint az alkalmazottaik így kevésbé kapcsolódnak egymáshoz, és a vezetők attól tartanak, hogy a fiatalabb szakemberek nem fejlödnek olyan ütemben, mint ha az irodákban, a tapasztalt kollégák mellett ülve, velük együtt dolgoznának.

Parker [2020] 24 országban több mint 1200 embert kérdezett meg, és a mintában szereplö 215 vezetö csaknem 40 százaléka arról számolt be, hogy alacsonyabb az önbizalma a home office-ban dolgozó alkalmazottaik vezetésével kapcsolatban. Ezt erősítik meg a Kürt Akadémia Live panelbeszélgetései is, amelyek során a harmadik leggyakoribb kockázatként a vezető szerepét és kommunikációját sorolták az érintettek a személyes kapcsolatok hiánya és a mentális megterhelés kapcsán. Poór és szerzőtársai [2020] ugyancsak kiemelték, hogy a válság idején a belső kommunikáció szerepe és jelentősége felértékelödött mind a vállalati vezetők, mind az alkalmazottak számára.

A Kürt Akadémia Live szakértői hangsúlyozták, hogy a válság alatt nemcsak a feladatokat, hanem az érzelmeket is „,vezetni kell”. „Az input helyett az emberre is figyelni.” (KAL [2020e]) A megkérdezett vállalati vezetők szerint nehéz volt magabiztosan, megbízhatóan és őszintén kommunikálni a megváltozott feltételek között. Felnőtt-felnőtt kommunikációra volt szükség, ami viszont sok helyen nem a természetes módja a kommunikációnak. „A vállalatoknál gyakran a felnőtt-gyermek jellegü kommunikáció van jelen, egy ilyen válság azonban igényli a felnőtt-felnőtt kommunikációt." (KAL [2020c])

A hiteles vezetői szerep még inkább felértékelödött, és kiderült, hogy kik is a kiemelkedő vezetők. Az egyik legnagyobb kihívás számukra a motivációvesztés és a különböző félelmek kezelése volt. „Motivált, egészséges csapattal lehet csak ebböl kijönni.”(KAL [2020b]) A vezetőknek egyszerre kellett megvédeniük a kollégáik fizikai és mentális egészségét, miközben a vállalatnak is zökkenőmentesen kellett müködnie.

Míg a szakirodalom a visszajelzések hiányát többnyire a home office negatív következményeként említi, az elvégzett tartalomelemzésböl arra a következtetésre jutottunk, hogy sok esetben a visszajelzések mennyisége még nőtt is. „Napi státuszmeeting volt.” (KAL $[2020 d])$ „Fontos nagyon figyelni a kollégákra, ezt meg is tettük, heti 
mood-check volt nálunk." (KAL [2020e]) A jó vezetök nem csupán az elvégzett munkára, hanem az alkalmazottaik mentális állapotára is odafigyeltek. „Egy videokonferencián, ha visszajelzünk munkatársunk utolsó mondatára, tudja, hogy figyeltünk a beszámolója végén. Ha az elejére is visszajelzünk, úgyérezheti, hogy végig figyeltünk. Ha pedig visszakérdezünk, hogy a múlt héten elmesélt, nehéz helyzete hogyan alakult, akkor valódi törődést élhet meg." (KAL [2020a])

\section{Informatikai kihívások}

A vállalkozásoknak a lezárások idején számos új informatikai problémával kellett szembenézniük, és egyre inkább az automatizált technológiákra építve kellett a folyamatokat úgy átalakítaniuk, hogy azzal a távolról dolgozókat kiszolgálják (VPN, felhőalapú technológiák, videokonferencia, fájlmegosztás). Ugyanakkor gyakoribbak lettek a kibertámadások, és nagyobb hangsúlyt kaptak az adatbiztonsági kérdések is (Lanz-Sussman [2020]).

A Xerox [2020] az Egyesült Államok, Kanada, az Egyesült Királyság, Franciaország és Németország nagyobb vállalatait érintő felmérése azt mutatta, hogy a cégeknek mindössze 28 százaléka volt technológiai szempontból felkészült a világjárványra. A válaszadók 29 százaléka vélekedett úgy, hogy a mostani válság volt az elmúlt évek legnehezebb kihívása. A távmunkára való átállás az Egyesült Államokban zajlott a legkönnyebben, míg a francia vállalatoknál volt a legnehezebb. A munkavállalók legtöbbször hiányolták az informatikai támogatást (35 százalék), a szoftverek elérhetőségét (27 százalék), valamint a kommunikációt és együttmüködést segítő eszközöket (22 százalék). Egytizedüknél hiányoztak a felhőalapú rendszerek is. A válaszadók egyharmada hangsúlyozta, hogy a legtöbb gond a hálózati és az adatbiztonsági problémákból adódott.

$\mathrm{Az}$ adatbiztonság terén e problémák idővel pozitív hatásokat eredményeztek. Kamiya és szerzötársai [2020] eredményei azt mutatták, hogy a személyes pénzügyi információk megszerzését célzó informatikai támadások az iparág egészének informatikai biztonságát növelték, ugyanis a támadásokkal közvetlenül nem érintett versenytársak is ilyen irányú fejlesztésekbe kezdtek. A fizikai kapcsolattartás elkerülésének igénye növelte az elektronikus fizetési módok iránti keresletet, és egyre többen döntöttek az online vásárlások mellett. Ezek a tendenciák arra kényszerítették a vállalatokat, hogy beruházzanak a megfelelő rendszerekbe és technológiákba. Megnőtt az automatizált gyártási technológiák iránti kereslet is (Lanz-Sussman [2020]). E megoldások bevezetése jelentős összegü informatikai beruházásokat igényelt, és ezek az informatikai fejlesztések növelték a tárhely- és a szerverkapacitás iránti igényeket is. Az elektronikus adatok megnövekedett mennyisége fejlettebb és gyorsabb adatfeldolgozási technikákat követelt. Már látható, hogy a versenyképesség kulcskérdése a jövőben az lesz, hogy a vállalatvezetők tudnak-e az ügyfelek gyorsan változó igényeire reagálva új üzleti modelleket és új stratégiákat alkalmazni. A legkézenfekvőbb e stratégiák közül továbbra is a digitális átalakulás. A digitalizáció élmezőnyében levő vállalatok a koronavírus-válság idején is prosperálnak, míg a digitalizációban lemaradó vállalatok a túlélésért küzdenek (George [2020]). Az informatikai fejlesztések különös 
kihívást jelentenek a korlátozott pénzügyi és szakmai erőforrásokkal rendelkező kkvszektor számára (Lanz-Sussman [2020]). A feladatok bonyolultsága integrált kockázatkezelési rendszereket igényelne, ám az integrált ERM rendszerek elsősorban éppen a kis- és középvállalatoknál hiányoznak.

Míg az informatikai kihívások és az adatbiztonsági kockázatok a válság indulásakor aggasztóak voltak hazánkban is, a $K A L$ [2020f] szakemberei arról számoltak be, hogy a legtöbb vállalat végül jól vette ezeket az akadályokat, és a kényszerhelyzetre gyorsan reagálva sikeresen át tudott állni az online müködésre. „Amiket éveken keresztül csak személyesen lehetett elintézni, azt most egy hét alatt meg lehetett oldani online." (KAL [2020f])

\section{A termelékenység változása}

A home office-beli munkavégzés termelékenységi hatása nem egyértelmű. Az otthoni munkavégzés miatt egyrészt csökkenhetett a hatékonyság, másrészt viszont a megtakarított utazási idő és az elektronikus információcsere növelhette is a teljesítményt. Schwantes [2019] szerint a válság előtt a távmunkások produktívabbnak bizonyultak. A járvány során azonban a menedzserek 38 százaléka egyetértett abban, hogy a távmunkások általában gyengébben teljesítenek, mint azok, akik az irodában dolgoznak. A megkérdezett vállalatvezetők 22 százaléka pedig nem tudott egyértelműen állást foglalni a kérdésben (Parker [2020]). A Xerox [2020] nemzetközi felmérésében a válaszadók 24 százaléka vélekedett úgy, hogy a munkavállalók termelékenységén érződik a pandémia negatív hatása. Idehaza a válaszadó HR-menedzserek 63 százaléka nem tapasztalt változást a teljesítményben, míg 22 százalékuk még javulást is érzékelt e téren (Digital Hungary [2020]).

Az Ernst \& Young és a HR Fest közös kutatásának eredményei szerint összességében nem csökkent a hatékonysága azoknak a hazai vállalkozásoknak, ahol minden kolléga távmunkában dolgozott a csaknem három hónapig tartó kijárási korlátozások alatt. A több mint 50 megkérdezett HR-vezető harmada a pozitív tapasztalatok hatására valamilyen formában hosszú távon is működtetni szeretné a home office-t (Pellion [2020]).

A Kürt Akadémia résztvevői szerint az alkalmazottak jellemzően másként vesznek részt az online találkozókon, mint az offline megbeszéléseken. „Az online meetingeken sok a párhuzamosan mást csináló kolléga, ami offline megbeszéléseken nem jellemzö. A fókuszidö majdnem harmadával esett vissza, hiszen az online meetingeken nehezebb hosszabb ideig koncentrálni." (KAL [2020a]) A monitor előtt gyakran elöfordul, hogy a résztvevők megosztják a figyelmüket, és párhuzamosan más feladatot végeznek. Ez a „multitasking” és a vele járó fókuszálási probléma a hatékonyság és a minőség rovására mehet. „A folyamatosan bejövő impulzusok mindig megzavarják a munkafolyamatokat, nehezebb most elmélyült munkát végezni. Elmélyülni és online kapcsolódni nem lehet egyszerre." (KAL [2020a])

A nemzetközi irodalom elemzése és a saját kutatásaink alapján a Covid-19 által okozott kockázatok megjelenési formájáról a 3. táblázat nyújt összefoglaló áttekintést. 
6. táblázat

A Covid-19 okozta kockázatok eltérő megjelenési formái

\begin{tabular}{ll}
\hline Személyes szint & Vállalati szint \\
\hline - több munkafeladat & - a kereslet ingadozása \\
- a munkanap „soha nem ér véget” & - az ellátási láncok problémái \\
- a munka és a magánélet keveredése & - adatbiztonsági kihívások \\
- túlterheltség (munka, házimunka, segítség & - ellenőrzési és irányítási problémák \\
a gyerekeknek a tanulásban) & - termelékenységi problémák \\
- a személyes kapcsolatok hiánya & - minőségromlás \\
- elmagányosodás & - fokozott bizonytalanság az üzleti \\
- karrierbeli bizonytalanságok & környezetben \\
- pénzügyi-megélhetési bizonytalanságok & - jogi és szabályozási kockázatok
\end{tabular}

Személyes kockázatok, amelyek egyúttal vállalati szintű kockázatok is

- alacsony motiváció

- a koncentrálás nehézségei

- az infrastrukturális és technológiai ismeretek hiánya

- nehézségek a csapatmunkában

- kommunikációs problémák

- a visszajelzés hiánya

- az informális kapcsolatok hiánya miatti veszteségek

- mentális problémák (depresszió, stressz, fáradtság, szorongás)

- fizikai problémák (fizikai aktivitás hiánya, túlsúly, mozgásszervi betegségek)

Forrás: saját szerkesztés.

\section{A Covid-19 okozta válság üzleti következményei}

A bemutatott kockázatok a vállalat értékét többféleképpen is érinthetik. A cash flow csökkenése és a jövőbeli növekedési lehetőségek korlátai mellett a bizonytalanság növeli a működési kockázatot és azon keresztül a tőkeköltséget is. A jövő kiszámíthatatlansága számos vállalkozás likviditási helyzetét ronthatja - ahogyan arról a Kürt Akadémia Live beszélgetéseinek résztvevői is említést tettek. „Rengeteg a bizonytalanság... Csináltunk pár szcenáriót, és folyamatosan figyeltünk..." (KAL [2020h])

A megtérülés, a nyereségesség és a likviditás kérdései

A válság következményei gyorsan megmutatkoztak a részvénypiacokon: a korábbi optimizmus megszünt, a vállalati kockázati felárak drámai módon emelkedtek. A 2020-as világgazdasági kilátások alig három hónap alatt a várt több mint 3 százalékos növekedésből 3 százalékos csökkenésre változtak. Ez az érték pedig rosszabb, mint a 20082009-es globális pénzügyi válság során tapasztalt veszteség (IMF [2020]).

2020. február végén a New York-i Értéktőzsde indexe drámaian zuhant, és a világ valamennyi nagyobb tőzsdéjén átlagosan 10-20 százalékos esést regisztráltak, és a Budapesti Értéktőzsde BUX-indexe is 30 százalékot esett április első napjaiban. Poór 
és szerzőtársai [2020] szerint a magyar vállalatok 40,1 százaléka az előző évhez képest 10 százaléknál nagyobb árbevétel-csökkenést várt 2020-ban. Az országok többségében kétféle gazdaságpolitikai válasz született a visszaesésre: a központi bankok hatalmas összegeket kezdtek pumpálni a pénzpiacokra, a kormányok pedig - ezzel egy időben gazdasági mentőcsomagokat hirdettek meg (Merce.hu [2020b]).

A válságnak leginkább kitett ágazatokban, valamint a nagyobb arányban intézményi befektetők kezében lévő vállalkozások esetében a kumulált abnormális hozam szignifikánsan alacsonyabb volt (vagyis az árfolyamuk nagyobb mértékben esett vagy kevésbé nőtt) ebben az időszakban. Ugyanakkor a jobb növekedési kilátású, kevesebb befektetett eszközzel müködő, magasabb tőkeáttételü és profitabilitású vállalatok kevesebb negatív hatással szembesültek (Xiong és szerzőtársai [2020]). Bár a legtöbb tanulmány a pénzügyi szektort a járvány által kevésbé sújtottak közé sorolja, a bankok is hatalmas kihívásokkal néztek szembe az elmúlt időszakban. A K\&H Bank mintegy 8 milliárd forint (22 millió euró) első negyedéves veszteséget jelentett 2020ban, és a nem teljesítő hitelek, valamint a kockázati költségek növekedése miatt további jelentős veszteségekre számíthattak (Harsányi [2020]).

$\mathrm{Az}$ alacsonyabb jövedelmezőség általában a likviditási helyzet romlásával járt együtt, de ugyanezt okozhatta a túl gyors termelésnövekedés is, ha a beruházások készpénzszükségletét nem fedezi a további nyereség. Így a járvány összességében súlyos hatással lehet a cégek likviditására is. De Vito-Gómez [2020] a Covid-19 likviditási hatásait vizsgálta 26 ország tőzsdén jegyzett cégeinek esetében. Tanulmányukban arra a következtetésre jutottak, hogy a vizsgált vállalatok egytizede fél éven belül csődbe mehet, ha a kereslet feltételezett visszaesése fennmarad, az átlagos vállalatok pedig két évet élhetnek túl, mielött a müködésük veszélybe kerülne. A súlyos következmények elkerülésére azt javasolták, hogy e cégek kapjanak haladékot az adók befizetésére, és a bankrendszer biztosítson számukra áthidaló kölcsönöket. A McKinsey [2021b] számításai szerint a tőzsdéken az olaj- és gázipari cégek jártak a legrosszabbul: az iparág összesített globális kapitalizációja 2020-ban 16,9 százalékkal esett. A polgári légi közlekedés 9,6, a pénzügyi szektor pedig 7,5 százalékot veszített értékéből. Ugyanakkor a média 35,7 , a fejlett elektronika 41,9 , a gépjármügyártás 45,3 , az informatikai szektor pedig 53,9 százalékos többlettel zárt.

Ungashick [2020] szerint hét tényező volt erös hatással a vállalatok értékcsökkenés nélküli üzemi eredményére (EBITDA) a pandémia alatt. Ezek a következők: 1. a bevételek vagy a nyereség átmeneti növekedése és csökkenése, 2 . a termelési rendszerek zavarai, 3. a távmunka támogatásának költségei, 4. a csökkentett alkalmazotti kompenzáció és létszám, 5. a növekvő adósságterhek, 6. a szállítói számlák késve fizetése, valamint 7. a kormányzati segítségek és hitelprogramok.

\section{Stratégiai hatások}

A Covid-19 okozta válság nyomán egyre több vállalat ismeri fel, hogy hosszabb távon kell gondolkodnia, és többet kell törődnie az értéket teremtő érintettjeivel - az alkalmazottaktól az ügyfeleken és a beszállítókon át a kockázatitőke-befektetőkig (Strebel 
[2020]). A PricewaterhouseCoopers is hasonló következtetésre jutott: szerintük a válság rámutatott arra, hogy az üzleti vállalkozások vezető szerepet töltenek be a társadalom egészében, így valamennyi érintettjük és a velük való kommunikáció egyaránt nagyon fontos. Az átláthatóság növeli a bizalmat, a bizalom pedig hosszú távon részvényesi értéket teremthet ( $P W C[2020])$.

2020 öszén a befektetőket az érdekelte legjobban, hogy az adott vállalat hogyan reagál a válságokra (PWC [2020], Jagdish [2020]). Bansal és szerzőtársai [2020] szerint azoknak az indiai cégeknek, amelyek rugalmatlanabbak, és nagyobb a müködésitőkeáttételük, rendszerint csökken a piaci értéke. Strebel [2020] szerint a cégeknek a likviditásuk megörzésére hosszabb távon csökkenteniük kell az osztalékokat és a részvény-visszavásárlásokat is. Hasonlókat fogalmazott meg George [2020] is: szerinte a mostani válság pozitív következménye, hogy a részvényeseknek eddig jutó eltúlzott figyelem mellett a többi érintett is fontossá vált a vállalatok számára.

\section{Növekedési lehetőségek}

A válság miatt számos cég elveszítette a növekedési potenciálját. Ennek egyik oka az, hogy az alacsonyabb jövedelmezőség korlátozza a beruházási terveket. Másrészt pedig a kereslet visszaesése és az ellátási láncok bizonytalanságai feleslegessé tették a gyártókapacitások egy részét. Emellett számos ágazat nagymértékben támaszkodik külföldi állampolgárságú munkavállalókra, akik a lezárások miatt - átmenetileg vagy véglegesen - visszatértek a hazájukba. A pandémia első fázisában a magyar vállalatok a leggyakrabban a szervezeti hatékonyságuk növelését, a költségek általános csökkentését, a beszerzések és a kiadások elhalasztását, valamint a stratégia átdolgozását alkalmazták a válság negatív hatásainak kiküszöbölésére vagy ellensúlyozására (Poór és szerzötársai [2020]). A Kürt Akadémia beszélgetéseiben is többször elökerült az újratervezés. „Azt terveztük, hogy terjeszkedni, növekedni fogunk a szállodai és fitneszszektorban. Most még nagyon messze vagyunk ettöl." (KAL [2020h])

\section{A működési kockázat növekedése}

Az ellátási láncokkal, az informatikai rendszerekkel, a hatékonysággal, a kereslettel és a munkakörnyezettel kapcsolatos bizonytalanságok nagyobb instabilitást és alacsonyabb kiszámíthatóságot eredményeznek. A Kürt Akadémia Live által szervezett beszélgetések során ez a kérdés különböző aspektusokból merült fel. Egyrészt a válságra adott vállalati reakciók gyakran „a káosz valamilyen szintjét” tükrözték. „Úgy viselkedtünk, mintha nem lenne holnap.” „Túl gyors döntések születtek... Most csinálhatjuk újra." (KAL [2020c]) Másrészt a jövő bizonytalansága egyre hangsúlyosabbá vált az üzleti döntések során. Fontos kérdéssé vált, hogy meddig kell, illetve meddig érdemes home office-ban dolgozni. „Uj szakasz lesz, amikor ebböl az örült home office-ból vissza kell lépni, de nem tudjuk, mi fog történni.” „A 90-100 százalékos home 
office szerintem nem hatékony. De vajon mekkora lenne az?" (KAL [2020f]) A szociális távolságtartás kérdése szintén többször elökerült a beszélgetések során. „A social life hiányzik a legjobban, miközben, ha visszamegyünk az irodába, az egyik fö szabály a social distancing lesz.” (KAL [2020f]) „Nehéz lesz megtanulni azokat az új rutinokat, amik nem természetesek. Például maszkot kell venni, ha a nyomtatóhoz vagy a mellékhelyiségbe megyünk. A megszokások legyözése nagy kihívás lesz... Például a kézfogást is el kell felejteni, ami nem fog menni néhány nap vagy hét alatt." (KAL [2020f])

\section{Változás az üzleti kultúrában}

Az üzleti kultúra változásai létfontosságúak lesznek a válságot követő időszakban. Khahro és szerzőtársai [2020] az építőipar példáján keresztül illusztrálták, hogy nemcsak megfelelő e-kommunikációs technikákat kell bevezetni, hanem felül kell vizsgálni az ügyféltárgyalásokat és a szerződéskötések hagyományos módját is. A pandémia utáni új korszak központi adatkezelést igényel online platformokon, amely jól használható az adott projekt tevékenységeinek nyomon követésére is. Ezek a változások az informatikai eszközökön és a továbbfejlesztett projekt- és kockázatkezelési gyakorlatokon alapuló újfajta munkakultúrát igényelnek.

A szervezetek nagyon hamar elkezdtek alkalmazkodni a változásokhoz. 2020 áprilisában a Statista [2020f] egy világméretű felmérést végzett. A válaszadók több mint fele a müködési hatékonyság növelésére (62 százalék), az üzleti folyamatok átalakítására (56 százalék), az ügyfélélmény javítására (55 százalék) és a kiberbiztonság javítására (55 százalék) koncentrált. Arkcoll [2020b] szerint az otthonról történő munkavégzéssel megváltoztak a szervezetek müködési keretei. Az értekezletek gyakoribbak lettek, mint korábban, a vezetők pedig többet és másként kommunikálnak. A Xerox [2020] megállapította, hogy a válság felgyorsította a digitális átalakulást, nőtt a vállalatok informatikai költségvetése, és a cégek most elsősorban arra összpontosítanak, hogy mind hardver-, mind pedig szoftveroldalon kielégítsék az alkalmazottak igényeit.

A KAL [2020b-d, 2020f-h] megszólaltatott szakemberei egyetértettek abban, hogy a világjárvány nyomása felgyorsította a változásokat, és növelte a szervezetek rugalmasságát. „Olyan irányelvekere van szükség, amelyekben néhány cövek le van verve, de kellő rugalmasság jellemzi őket, és lehetöséget adnak a folyamatos iterációra... Csak iterációs, közelítö folyamatokkal lehet megtalálni az optimális utat." (KAL [2020h]) Különösen a digitalizációval és a munkavállalók jóllétével kapcsolatos vállalati döntések gyorsultak fel. „A vírus akcelerátorként müködött: olyan fejlödési utat jártunk be a digitalizációban és a home office-ban, amire egyébként évtizedek kellettek volna." (KAL [2020f]) „Itt van például a well-being... Eddig erről mindenki csak beszélt, most viszont el kellett kezdeni csinálni." (KAL [2020b])

Kutatásunk lezárásaként a Covid-19 üzleti kockázatainak eredetére, megjelenésére és következményeire vonatkozó megállapításainkat egy kockázati térképen 
foglaltuk össze (lásd az 1. ábrát). A legfontosabb megállapításunk az, hogy a számos feldolgozott forrás ellenére sem találtunk olyan kockázatokat, amelyek kifejezetten a válság hatására, újonnan jelentek volna meg. Sokkal inkább az történt, hogy a korábban ismert kockázatok nagyobb erővel és más kockázatokkal egy időben léptek fel. Emiatt a korábbi kockázatkezelő rendszerek sok területen csődöt mondtak, a kockázatok közti együttmozgás erösödése miatt pedig a békeidők alapján becsült erőfor rás-tartalékok már nem bizonyultak elegendőnek. A problémák jellemzően nem abból adódtak, hogy újfajta kockázatok jelentek volna meg, hanem abból, hogy a „normál” terhelésnél jól teljesítő kockázatkezelési rendszerek a válság „stressztesztjén” megbuktak. A jó hír tehát az, hogy nem kell újféle kihívásokra megoldásokat keresni, csupán a korábbinál nagyobb valószínüséggel bekövetkező extrém helyzetekre kell felkészülniük a vállalatoknak. Összehasonlításképpen: olyan ez, mint a globális felmelegedés miatt a szélsőséges időjárási helyzetek megugró gyakorisága.

1. ábra

A Covid-19 okozta válság vállalati kockázati térképe

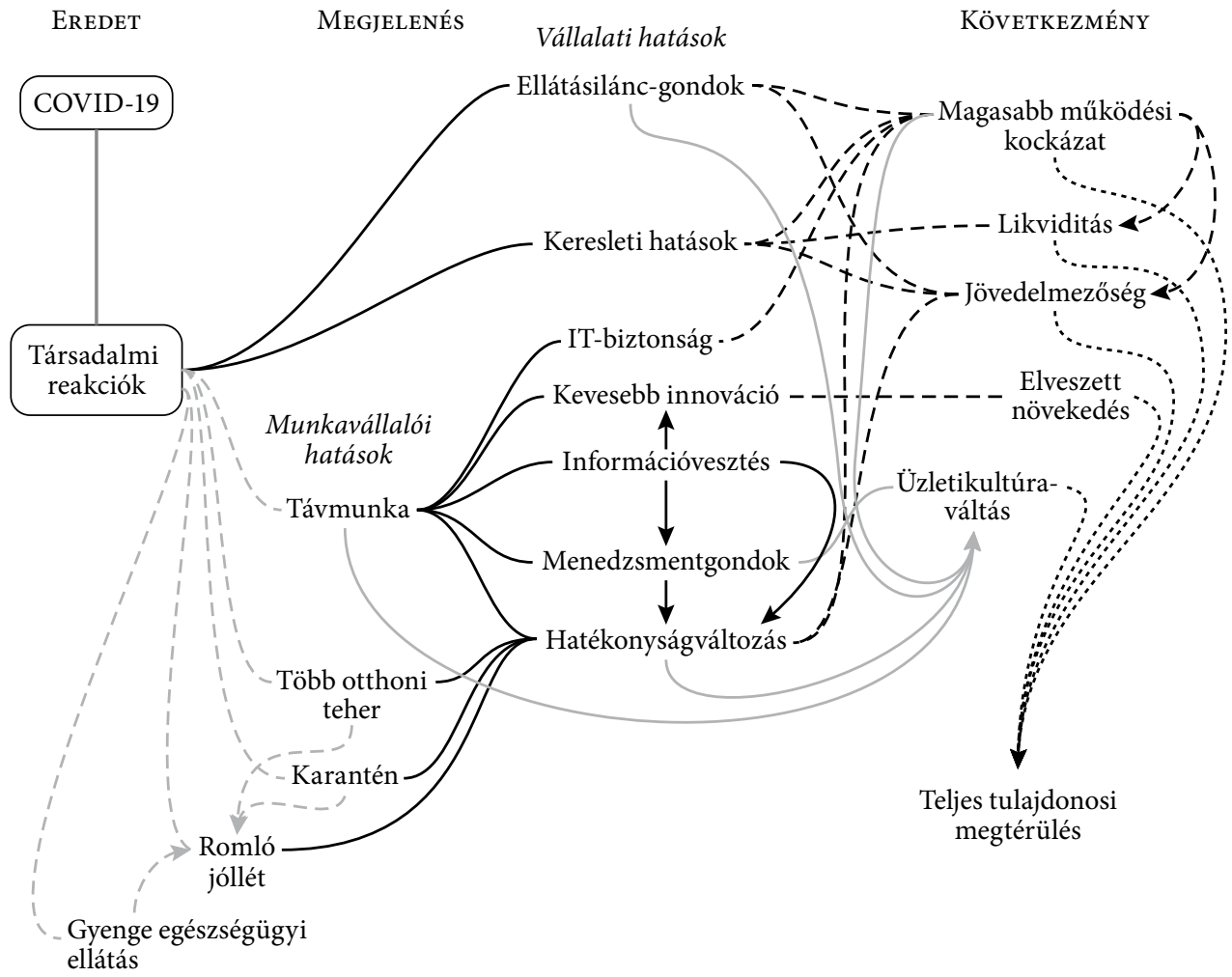




\section{Összegzés}

A Covid-19-járvány hatásai új kockázati forrásként jelentek meg a vállalatoknál 2020 elején, olykor súlyos üzleti következményekkel, amelyek azonnali cselekvést igényeltek. Egy adott kockázatrendszer hatékony kezeléséhez mindenekelött kockázati térképet kell készítenünk. Cikkünk ehhez a legfontosabb kihívásokat tekintette át a vonatkozó irodalom feldolgozására, forráselemzésre, kérdőíves felmérésekre és kvalitatív mélyinterjúkra építve. Eredményeink szerint a kockázatok közvetlen vállalati hatásain túl meghatározók voltak a közvetett hatások is, amelyeket elsősorban a járvány munkavállalókra gyakorolt közvetlen hatásai magyaráznak. Fontosnak tartjuk kiemelni, hogy a járvány munkavállalói hatásai egyúttal a lakossági végfelhasználókra, valamint az üzleti partnerek és a versenytársak alkalmazottaira gyakorolt hatások is - vagyis áttételesen a közvetlen vállalati hatások magyarázó tényezői is.

Kutatásunk lényeges eredménye, hogy egyetlen olyan kockázati formát sem sikerült azonosítanunk, amelyik önmagában újdonság lenne a vállalatok számára. Sokkal inkább a korábban ritkán megjelenő kockázatok (a távmunka terjedése, a munkavállalók egészségügyi problémái, ellátási gondok, a kereslet hirtelen változása) gyakorisága és hatásuk nagysága nőtt meg, ráadásul a különféle kockázatok együttesen, egy időben is jelentkeztek. A vállalatok számára elsősorban a sokféle kockázat egyidejü fellépése és a korábbi kockázati mértékekhez igazított kockázatkezelési eszközök elégtelensége jelentette a legnagyobb kihívást.

Általános tanulság, hogy a közvetett következmények hatékonyabb kezelése érdekében a vállalatoknak nagyobb figyelmet kell fordítaniuk az alkalmazottaik jóllétére. Ehhez jóval részletesebb ismeretekre van szükség a munkavállalókról, az ő életkörülményeikről, érzéseikről annál, mint amilyennel a vállalatok a formális csatornáik révén rendelkeznek. A kockázati hatások országonként alig különböznek, mégis igen eltérők lehetnek a különböző iparágak és egyének között; egyes ágazatoknál e hatások később vagy időben változó módon jelentkezhetnek, ráadásul számos vállalat pozitív hatásokat is tapasztalt a müködésének bizonyos területein.

Az egyes kockázatok megjelenésének és következményeinek elkülönítésével cikkünk hozzájárulhat ahhoz, hogy rálássunk a világjárvány első hullámában azonosított problémák összefüggéseire. Ez azért lehet különösen fontos, mert a szakértők szerint a hasonló járványok a jövőben még gyakoribbak lesznek, így a mostani válság tanulságainak a vállalati kultúrába való beépítése hosszabb távon is szolgálhatja a tulajdonosi értékteremtést.

A kutatás eredményeinek alkalmazhatóságát természetesen korlátozhatja, hogy vizsgálatunk csak az első hullámra terjedt ki, és nagyrészt kvalitatív jellegü volt. A következő lépés az lehet, hogy a járvány további hullámainak hatásait is vizsgálva, lehetőség szerint egy matematikai modell is készül a kockázatok nyomon követésére. 


\section{Hivatkozások}

Aldana, S. G. [2001]: Financial Impact of Health Promotion Programs: A Comprehensive Review of the Literature. American Journal of Health Promotion, Vol. 15. No. 5. 296-320. o. https://doi.org/10.4278/0890-1171-15.5.296.

Andrade, C. [2020a]: Covid-19 and Lockdown: Delayed Effects on Health. Indian Journal of Psychiatry, Vol. 62. No. 3. 247-249. o. https://doi.org/10.4103/psychiatry.IndianJ Psychiatry_379_20. Letöltés ideje: 2020.02.20.

Andrade, C. [2020b]: Understanding Delayed Effects on Health of Covid-19 and Lockdown. https://www.deccanherald.com/opinion/understanding-delayed-effects-on-health-ofCovid-19-lockdown-825968.html.

Anton, S. G. [2018]: The Impact of Enterprise Risk Management on Firm Value: Empirical Evidence from Romanian Non-Financial Firms. Engineering Economics, Vol. 29. No. 2. 151-157. o. https://doi.org/10.5755/j01.ee.29.2.16426.

Arkcoll, P. [2020a]: Measure How Your Organisation is Adapting to WFH. LinkedIn: https://www.linkedin.com/pulse/measure-how-your-organization-adapting-wfhphilip-arkcoll/. Letöltés ideje: 2020. 02.20.

Arkcoll, P. [2020b]: Update: The Impact of Covid-19/WFH on Work Habits. Worklytics: https://www.worklytics.co/update-the-impact-of-Covid-19-wfh-on-work-habits/. Letöltés ideje: 2020. 02. 20.

Assari, S.-LAnkarani, M. M. [2016]: Stressful Life Events and Risk of Depression 25 Years Later: Race and Gender Differences. Frontiers in Public Health, Vol. 4. No. 49. https://doi. org/10.3389/fpubh.2016.00049.

BAKONyi Zoltán-Kiss-Dobronyi Bence [2020]: A Covid-19 járvány hatása a munkavégzésre. Gyorsjelentés I. http://tavmunka-kutatas.hu/assets/files/gyorsjelentes_0420_v1.pdf. Letöltés ideje: 2020. 02. 20.

Bansal, A.-Gopalakrishnan, B.-Joshy, J.-Srivastavak, P. [2020]: When the market went viral: Covid-19, stock returns, and firm characteristics. Preliminary draft. https://www. researchgate.net/publication/342153767_When_the_market_went_viral_COVID19_stock_ returns_and_firm_characteristics/link/5ee86f77a6fdcc73be7fc2d5/download. Letöltés ideje: 2020. 02.20.

CNN Health [2020]: Tracking coronavirus' global spread. CNN: https://edition.cnn.com/ interactive/2020/health/coronavirus-maps-and-cases/. Letöltés ideje: 2020. 02. 20.

Cutter, C. [2020]: Companies Start to Think Remote Work Isn't So Great After All. The Wall Street Journal: https://www.wsj.com/articles/companies-start-to-think-remote-workisnt-so-great-after-all-11595603397. Letöltés ideje: 2020. 02. 20.

Czeisler, M. É.-Lane, R. I.-Petrosky, E.- Wiley, J. F-Christensen, A.-Njai, R.-Weaver, M. D.-Robbins, R.-Facer-Childs, E. R.-BArger. L. K.-Czeisler, Ch. A.-Howard, M. E.-Rajaratnam, S. M. W. [2020]: Mental Health, Substance Use, and Suicidal Ideation During the Covid-19 Pandemic - United States, June 24-30, 2020. MMWR Morbidity and Mortality Weekly Report, 2020. augusztus 14. No. 69. 1049-1057. o. https://doi. org/10.15585/mmwr.mm6932a1.

De Vito, A.-Gómez, J. [2020]: Estimating the Covid-19 Cash Crunch: Global Evidence and Policy. Journal of Accounting and Public Policy, Vol. 39. No. 2. 1-14. o. https://doi. org/10.1016/j.jaccpubpol.2020.106741. 
Digital Hungary [2020]: Home office gyerekkel, gyerek nélkül: bevált-e a távmunka? https://www.digitalhungary.hu/e-volution/Home-office-gyerekkel-gyerek-nelkulbevalt-e-a-tavmunka/9700/. Letöltés ideje: 2020. 02. 20.

Emerson, E.-Fortune, N.-Llewllyn, G.-Stancliffe, R. [2020]: Loneliness, Social Support, Social Isolation and Wellbeing among Working Age Adults with and without Disability: Cross Sectional Study. Disability and Health Journal, Vol. 14. No. 1. 1-7. o. https:// doi.org/10.1016/j.dhjo.2020.100965.

Fukase, Y.-Ichikura, K.-Murase, H.-Tagaya, H. [2021]: Depression, risk factors, and coping strategies in the context of social dislocations resulting from the second wave of Covid-19 in Japan. BMC Psychiatry, Vol. 21. No. 33. https://doi.org/10.1186/s12888-021-03047-y.

Gajendran, R. S.-Harrison, D. A. [2007]: The Good, the Bad, and the Unknown About Telecommuting: Meta-Analysis of Psychological Mediators and Individual Consequences. Journal of Applied Psychology, Vol. 92. No. 6. 1524-1541. o. https://doi.org/10.1037/00219010.92.6.1524.

GEORGE, B. [2020]: The coronavirus crisis has accelerated the shift to stakeholder capitalism. https://fortune.com/2020/05/12/coronavirus-corporate-social-responsibility.

Gonzalez, D.-Karpman, M.-Kenney, G. [2020]: Parents are Struggling to Provide for Their Families During the Pandemic. Health Reform Monitoring Survey. Robert Wood Johnson Foundation: https://www.rwjf.org/en/library/research/2020/05/parents-are-struggling-toprovide-for-their-families-during-the-pandemic.html. Letöltés ideje: 2020. 08. 01.

HAROMKirALYFi.Hu [2020]: Még több home office-t akarnak a dolgozók. https://www. haromkiralyfi.hu/20200609-meg-tobb-home-office-t-akarnak-a-dolgozok. Letöltés ideje: 2021. 02. 20.

HARSÁNYi PÉTER [2020]: K\&H-vezér: a járvány második hulláma likviditási válságot is előidézhet. https://novekedes.hu/interju/kh-vezer-a-jarvany-esetleges-masodik-hullamalikviditasi-valsagot-is-eloidezhet. Letöltés ideje: 2020. 08. 26.

HRFEST [2020]: Kutatás a távmunkáról - eredmények. https://hrfest.com/hr-fest-online-27batiz-andras-es-terray-tamas-kutatas-a-tavmunkarol-eredmenyek/. Letöltés ideje: 2020. 06. 28.

IMF [2020]: Global Financial Stability Report. http://financial-stability.org/wp-content/ uploads/2020/04/2020-04_IMF_global-financial-stability-report_full-report.pdf. Letöltés ideje: 2021. 02. 20.

Ivanov, D. [2020]: Predicting the Impacts of Epidemic Outbreaks on Global Supply Chains: A Simulation-Based Analysis on the Coronavirus Outbreak (Covid-19/SARS-CoV-2) Case. Transportation Research Part E. Logistics and Transportation Review, Vol. 136 (April). https://doi.org/10.1016/j.tre.2020.101922.

Kamiya, S.-Kang, J.-Kim, J.-Milidonis, A.-Stulz, R. M. [2020]: Risk Management, Firm Reputation, and the Impact of Successful Cyber attacks on Target Firms. Journal of Financial Economics, Vol. 139. No. 3. 719-749. o. https://doi.org/10.1016/j.jfineco.2019.05.019.

KaZainé Ónodi Annamária [2020]: A távmunka jövője. 179. sz. műhelytanulmány. Budapesti Corvinus Egyetem Vállalatgazdaságtan Intézet, http://unipub.lib.uni-corvinus. hu/5716/1/Kazaine_179.pdf. Letöltés ideje: 2020.06. 28.

Khahro, S. H.-Ali, T. H.-Vighio, A. A.-Khahro, Q. H.-Moriyani, M. A. [2020]: Post Pandemic Project Management Key Skills and Challenges. Talent Development and Excellence, Vol. 12. No. 3. Special Issue 2253-2260. o. ISSN: 1869-0459.

Kraus, S.-Grzech-Sukalo, H.-Rieder, K. [2020]: Mobile Arbeit - Home-Office, Dienstreisen, Außendienst - was ist wirklich belastend? Zeitschrift für Arbeitswissenschaft, Vol. 74. 167-177. o. https://doi.org/10.1007/s41449-020-00214-x. 
LanZ, J.-Sussman, B. I. [2020]: Information Security Program Management in a Covid-19 World. CPA Journal, Vol. 90. No. 6. 28-35. o.

McKinsey [2021a]: Achieving an inclusive US economic recovery, február 3. https://www. mckinsey.com/industries/public-and-social-sector/our-insights/achieving-an-inclusiveus-economic-recovery\#. Letöltés ideje: 2021. 02. 25.

MCKINSEY [2021b]: Market valuation of sectors in 2020. https://covid-tracker.mckinsey.com/ financial-impact-sector?cid=other-eml-alt-mip-mck\&hdpid=2b9dd831-5bcc-44cd-99a2e114cac59118\&hctky=1957264\&hlkid $=88003063$ c0e04fd4a50036d7be06cd69. Letöltés ideje: 2021. 02. 28.

Murphy, J. F.-Jones, J.-Conner, J. [2020]: The Covid-19 Pandemic: Is It a 'Black Swan'? Some Risk Management Challenges in Common with Chemical Process Safety. Process Safety Progress, Vol. 39. No. 2. https://doi.org/10.1002/prs.12160.

Nocco, B. W.-STUlz, R. M. [2006]: Enterprise Risk Management: Theory and Practice. Journal of Applied Corporate Finance, Vol. 18. No. 4. 8-20. o. https://doi.org/10.1111/j.17456622.2006.00106.x.

Parker, S. K.-Knight, C.-Keller, A. [2020]: Remote Managers Are Having Trust Issues. Harvard Business Review: https:/hbr.org/2020/07/remote-managers-are-having-trustissues. Letöltés ideje: 2020. 08. 22.

Pellion Ágnes [2020]: Bevált a távmunka a hazai cégeknél. https://www.ey.com/hu_hu/ news/2020-press-release/6/bevalt-a-tavmunka-a-hazai-cegeknel. Letöltés ideje: 2020. 09. 22.

Poór József-Balogh Gábor-Dajnoki Krisztina-Karoliny Mártonné-Kun András IstváN-Sza BÓ SzILvia [2020]: Koronavírus-válság - kihívások és HR-válaszok. A kutatás első fázisának kiértékelése. Kutatási jelentés. https://mkik.hu/ckfinder/files/KoronaHR_ kutata\%CC\%81si-jelente\%CC\%81s.pdf. Letöltés ideje: 2021. 02. 22.

PWC [2020]: Covid-19: As your company steps up ... speakup. https://www.pwc.com/us/ en/cfodirect/publications/point-of-view/Covid-19-companies-response-measures-tostakeholders.html. Letöltés ideje: 2020. 10. 02.

Ramos, D.-Afonso, P.-Rodrigues, M. A. [2020]: Integrated Management Systems as a Key Facilitator of Occupational Health and Safety Risk Management: A Case Study in a Medium Sized Waste Management Firm. Journal of Cleaner Production, Vol. 262. https:// doi.org/10.1016/j.jclepro.2020.121346.

Recchi, E.-Ferragina, E.-Helmeid, E.-Pauly, S.-Safi, M.-Sauger, N. -Schradie, J. [2020]: The 'Eye of theHurricane' Paradox: An Unexpected and Unequal Rise of Well-Being During the Covid-19 Lockdown in France. Research in Social Stratification and Mobility, Vol. 68. https://doi.org/10.1016/j.rssm.2020.100508.

Schwantes, M. [2019]: A New Study Reveals Why Working From Home Makes Employees More Productive. https://www.inc.com/marcel-schwantes/new-study-reveals-why-workingfrom-home-makes-workers-more-productive.html. Letöltés ideje: 2020. 06. 28.

Sharma, A.-Pillai, D. R.-Lu, M.-Doolan, C.-Leal, J.-Kim, J.-Hollis, A. [2020]: Impact of Isolation Precautions on Quality of Life: A Meta-Analysis. Journal of Hospital Infection, Vol. 105. No. 1. 35-42. o. https://doi.org/10.1016/j.jhin.2020.02.004.

SETH, J. [2020]: Business of business is more than business: Managing during the Covid crisis. Industrial Marketing Management, Vol. 88. (May) 261-264. o. https://doi.org/10.1016/j. indmarman.2020.05.028.

Silva, J. R.-DA Silva, A. F.-Chan, B. L. [2019]: Enterprise Risk Management and Firm Value: Evidence from Brazil. Emerging Markets Finance and Trade, Vol. 55. No. 3. 687-703. o. https://doi.org/10.1080/1540496X.2018.1460723. 
STATista [2020a]: In what way does the coronavirus (Covid-19) affect your company? https://www.statista.com/statistics/1107656/hungary-enterprise-problems-caused-bycoronavirus-2020/. Letöltés ideje: 2020. 08. 25.

STATISTA [2020b]: Which of the following are the greatest challenges when working from home in light of the corona situation? https://www.statista.com/statistics/1110727/ challenges-with-working-from-home-during-the-coronavirus-pandemic-in-denmark. Letöltés ideje: 2020. 06. 28.

StATista [2020c]: Impact of working from home on the work-life balance of marketers during the coronavirus pandemic in the United Kingdom in 2020. https://www.statista. com/statistics/1104762/coronavirus-home-office-and-work-life-balance-of-uk-marketers. Letöltés ideje: 2020. 06. 28.

Statista [2020d]: Struggles with working remotely 2020. https://www.statista.com/ statistics/1111316/biggest-struggles-to-remote-work. Letöltés ideje: 2020. 06. 28.

Statista [2020e]: What is your opinion about the period when you had to do home office because of the coronavirus (Covid-19) epidemic? https://www.statista.com/statistics/1116390/ romania-home-office-during-Covid-19-in-romania. Letöltés ideje: 2020. 06. 28.

STATISTA [2020f]: How has the pandemic impacted the way your organisation is prioritising the following business initiatives? https://www.statista.com/statistics/1131705/post-covidit-priorities-business-initiatives/. Letöltés ideje: 2020. 08. 25.

Strebel, P. [2020]: Covid-19 is turning the tables on short-terms hareholders. IMD: https://www.imd.org/research-knowledge/articles/COVID-turning-tables-short-termshareholders/, Letöltés ideje: 2020. 10. 20.

SzOLIDARITÁsi AKCiócsoport [2020a]: A koronavírus hatása a munka világára és a munkavállalókra. https://merce.hu/2020/04/11/a-koronavirus-hatasa-a-munka-vilagara-es-amunkavallalokra/. Letöltés ideje: 2020. 08. 23.

Szolidaritási Akciócsoport [2020b]: Nem térhetünk vissza a normális müködéshez, mert a normális működés maga a probléma. https://merce.hu/2020/04/11/nem-terhetunkvissza-a-normalis-mukodeshez-mert-a-normalis-mukodes-maga-a-problema/. Letöltés ideje: 2020. 08. 23.

Torontáli Zoltán [2020]: Amióta nem kell bejárni dolgozni, nagyon rámentek az emberek az otthoni barkácsolásra. G7.hu: https://g7.hu/vallalat/20200823/amiota-nem-kellbejarni-dolgozni-nagyon-ramentek-az-emberek-az-otthoni-barkacsolasra/. Letöltés ideje: 2020. 08. 24.

Total Brain [2020]: Working Women Bear the Emotional Brunt of Covid-19. https://www. totalbrain.com/working-women-bear-the-emotional-brunt-of-Covid-19-anxiety-drivingpoor-workplace-performance-according-to-the-mental-health-index-u-s-worker-edition/. Letöltés ideje: 2020. 08. 24.

Ungashick, P. [2020]: Maximizing Company Value: Tracking EBITDA During COVID. https://www.navixconsultants.com/the-exit-playbook/maximizing-company-valuetracking-ebitda-during-covid. Letöltés ideje: 2020. 10. 03.

Van Dongen, J. M.-Proper, K. I.-Van Wier, M. F.-Van der Bee, A. J.-Bongers, P. M.-Van Mechelen, W.-VAn Tulder, M. V. [2011]: Systematic Review on the Financial Return of Worksite Health Promotion Programmes Aimed at Improving Nutrition and/or Increasing Physical Activity. Obesity Reviews, Vol. 12. No. 12. 1031-1049. o. https://doi.org/10.1111/ j.1467-789X.2011.00925.x.

WANG, X.-LeI, S. M.-Le, S.-YAng, Y.-Zhang, B.-YAo, W.-GaO, Z.-Cheng, S. [2020]: Bidirectional Influence of the Covid-19 Pandemic Lockdowns on Health Behaviors and Quality 
of Life among Chinese Adults. International Journal of Environmental Research and Public Health, Vol. 17. No. 15. 5575. o. https://doi.org/10.3390/ijerph17155575.

Wellable [2020a]: 7 Stats on Covid-19's Impact on Employee Mental Health. https://blog. wellable.co/7-stats-on-Covid-19s-impact-on-employee-mental-health. Letöltés ideje: 2021. 02. 20.

Wellable [2020b]: Mental Health Conditions Remain Elevated as Pandemic Continues. https://blog.wellable.co/mental-health-conditions-remain-elevated-as-pandemiccontinues. Letöltés ideje: 2020. 02. 20.

Welt.DE [2020a]: Diese Branche profitiert offenbar von der Corona-Krise. https://www.welt. de/wirtschaft/video213762296/Umsatzplus-Diese-Branche-profitiert-offenbar-von-derCorona-Krise.html?cid=onsite.onsitesearch. Letöltés ideje: 2020. 08. 24.

Welt.de [2020b]: Büro oder Home office? Dann doch lieber einen Schreibtisch im Fernsehturm. https://www.welt.de/wirtschaft/karriere/article213699022/Buero-oder-HomeofficeIndependesk-vermittelt-Schreibtische-ueberall.html. Letöltés ideje: 2020. 08. 24.

WHO [2021]: WHO Coronavirus Disease [Covid-19]. https://covid19.who.int/?gclid=EAI aIQobChMIzu_5rI2y6wIVROmyCh3gSA5XEAAYASAAEgLwZvD_BwE. Letöltés ideje: 2021. 02. 25.

WORLDOMETERs [2021]: Countries in the world by population. https://www.worldometers. info/world-population/population-by-country/. Letöltés ideje: 2021. 0224.

Wronski, L. [2020]: NBC News| Survey Monkey poll: coronavirus and the economy. https:// www.surveymonkey.com/curiosity/nbc-poll-covid-july5/. Letöltés ideje: 2020. 08. 23.

Xerox [2020]: 82\% of Employees Expected to Return to the Office in 12-18 Months. https:// www.news.xerox.com/news/global-Xerox-Future-of-Work-Survey-results. Letöltés ideje: 2020. 08. 23.

Xiong, H.-Wu, Z.-Hou, F.-Zhang, J. [2020]: Which Firm-Specific Characteristics Affect the Market Reaction of Chinese Listed Companies to the Covid-19 Pandemic? Emerging Markets Finance and Trade, Vol. 56. No. 10. 2231-2242. o. https://doi.org/10.1080/15404 96X.2020.1787151.

\section{Interjúk és panelbeszélgetések ${ }^{1}$}

FARAGó István [2020]: Interjú a Covid-19 hatásairól, következményeiről. Stressz-M és Mental Coffee, alapító tulajdonos, Budapest, július 24.

HoRvÁTH EMIL LÁszLó [2020]: Interjú a Covid-19 hatásairól, következményeiről. Egészségesebb Munkahelyekért Egyesület (EMEGY) elnöke, stresszmentor, Budapest, július 25.

KAL [2020a]: Van élet a folyosói pletyka nélkül? Kürt Akadémia Live, https://kurtakademia. hu/blog/kurt-akademia-live-1-7-izgalmas-gondolat-a-munkahelyi-halozatokrol.

KAL [2020b]: Vészhelyzet vagy észhelyzet. Kürt Akadémia Live, https://kurtakademia. $\mathrm{hu} / \mathrm{blog} /$ kurt-akademia-live-2-7-izgalmas-gondolat-a-rugalmasan-alkalmazkodovallalatokrol-es-vezetokrol.

KAL [2020c]: A boardroomból jelentjük 1. Kürt Akadémia Live, https://kurtakademia.hu/ blog/kurt-akademia-live-3-7-izgalmas-gondolat-a-krizishelyzet-menedzseleserol/.

KAL [2020d]: Vírusmarketing. Kürt Akadémia Live, https://kurtakademia.hu/blog/kurtakademia-live-4-7-izgalmas-gondolat-a-virusmarketingrol/.

\footnotetext{
${ }^{1}$ A panelbeszélgetések letöltési ideje: 2021. 07. 20.
} 
KAL [2020e]: A boardroomból jelentjük 2. Kürt Akadémia Live, https://kurtakademia.hu/ blog/kurt-akademia-live-5-7-izgalmas-gondolat-az-agilis-termekfejlesztesrol/.

KAL [2020f]: A boardroomból jelentjük 3. Kürt Akadémia Live, https://kurtakademia.hu/ blog/kurt-akademia-live-6-7-kulcsgondolat-az-irodai-visszateresrol/.

KAL [2020g]: Spotlightban az adattudós. https://kurtakademia.hu/blog/kurt-akademia-live7-7-kulcsgondolat-a-jarvanymodellezesrol/.

KAL [2020h]: Vállalati restart. https://kurtakademia.hu/blog/kurt-akademia-live-8-7kulcsgondolat-a-vallalati-restartrol/.

MÁRKy ÁdÁm [2020]: Interjú a Covid-19 hatásairól, következményeiről. Longevity Project, alapító tulajdonos, Budapest, július 22.

\section{Függelék}

\section{F1. táblázat}

A Kürt Akadémia Live panelbeszélgetései

\begin{tabular}{ll}
\hline Időpont & Résztvevők \\
\hline 2020. április 15. & Szvetelszky Zsuzsa hálózatkutató \\
& Vicsek András hálózatkutató, Maven7
\end{tabular}

2020. április 22. Byssz Róbert, a Philips globális transzformációs igazgatója Márky Ádám, a Longevity Project alapítója, orvos, rezilienciakutató Kürti Tamás, a Kürt Akadémia tulajdonos-intézményvezetője

2020. április 29. Ifj. Chikán Attila, az ALTEO Nyrt. vezérigazgatója Heiszler Gabriella, a SPAR Magyarország ügyvezető igazgatója Küllői Péter, a Bátor Tábor Alapítvány elnöke, a Tate Modern középeurópai bizottságának társelnöke

2020. május 6. Kormos Dalma, a Bridge Budapest és a Nyitottak Vagyunk kommunikációs vezetője, független kommunikációs szakértő Pőcze Balázs, a Mito egyik alapítója, kreatív igazgatója Szabó Béla, a Magyar Telekom csoport kommunikációs igazgatója

2020. május 13. Schiller Márk, a Schiller Autó Család marketingvezetője Simák Pál, a CIB Bank Zrt. elnök-vezérigazgatója Szabó Melinda, a Magyar Telekom Nyrt. kereskedelmi vezérigazgató-helyettese

2020. május 20. Kelemen Béla, a MOL Nyrt. Business Excellence alelnöke Mihók Krisztina, az ERSTE Bank Hungary Zrt. HR-igazgatója Tátrai Bernadett, a Fundamenta-Lakáskassza Zrt. elnök-vezérigazgatója

2020. május 27. Bátorfy Attila újságíró, adatvizualizációs szakember Nepusz Tamás bioinformatikus Röst Gergely járványmodellezéssel foglalkozó matematikus

2020. június 3. Gazsi Zoltán, az Eisberg Hungary Kft. ügyvezető igazgatója Mizsei Szabolcs, digitális transzformációs szakértő Vityi Péter, a Kürt Akadémia ügyvezetője

Forrás: saját szerkesztés. 